\title{
ТИПОЛОГИЯ МЕДИАРЕЧИ
}

UDC 32.01

\section{Language manipulation strategies of the political advertising in Bulgaria}

\author{
G. L. Manolov \\ Higher School of Security and Economics, \\ 13, Kuklensko Shousse, Plovdiv, 4000, Bulgaria
}

For citation: Manolov, G.L. (2018). Language manipulation strategies of the political advertising in Bulgaria. Media Linguistics, 5 (4), 545-556. https://doi.org/10.21638/spbu22.2018.412

\begin{abstract}
The present article considers the nature and specifics of the term "language manipulation strategies" in Bulgaria. This is achieved on the grounds of the clarification of manipulation (as definiteness) and of its importance upon its use in various pre-election campaigns. In connection with this, this article determines the meaning of language manipulation strategies, their scientific nature, as well as their main purpose in the pre-election fight. In addition, the key elements of the so-called "language of change" (after 10.11.1989) in Bulgaria are presented herein, just like the lexical occasionalisms, lexical neologisms, semantic neologisms, the change in the stylistic shade, etc. This article presents a detailed analysis of the so-called "language play" in the advertising text of the respective political subjects. Besides the definiteness of the term in a synthesized order, this article presents six leading variants of a language play play advertising methods (quotation), a play upon phraseology, methaphorical nomination, a play upon syntagmatics, occasional word creation, and a play upon the black and white drawing. These language plays are also illustrated with the respective examples from preelection campaigns. Special attention is paid to the manipulation rules of political advertising, such as the establishment of the brand (mark), the successful device (slogan, motto), the easy messages, the language manipulations, the "sale" of the charisma, brief speaking, conscious repetition, fabrication, no lies, and "proper" manipulation.
\end{abstract}

Keywords: language manipulation strategies, language play, manipulation, political manipulation, rules of political manipulation

Problem formulation. The manipulation during elections is one of the most striking and distinctive functions of the political advertising. This function is very important due to the fact thats its application may win or ruin the pre-election campaigns of political

() Санкт-Петербургский государственный университет, 2018 
subjects. In view of the above, upon the development of their political advertising the parties count on a cannonade of language means used for the development of the so-called "language manipulation strategies" in the pre-election fight.

Most generally speaking, the language manipulation strategies are a combination of true/false language statements, expressions and means (lexical, stylistical, morphological, etc.), which are used by means of political advertising to manipulate the public, and especially the electorate during the pre-election campaigns (in favor of different political players).

Goals and tasks. The main objective of the present paper is to draw out and define the linguistic manipulative strategies of political advertising in Bulgaria, as well as to analyze their essence.

As a realization of the stated goal, the following research objectives are also set: first, revealing the more significant changes in the political language in the course the posttotalitarian transition; secondly, systematizing the basic options of the so-called "language play" in the use of linguistic manipulative strategies in politics; and thirdly, evocation of the most commonly used manipulative rules of the political advertising during election campaigns.

Methods of analysis. In the Bulgarian pluralistic political life these strategies have their own history dating back to the beginning of the democratic changes, when a number of new words (and combinations of words) entered the political language, as those were broadly used both in public activities and in political advertising. The above, of course, resulted in a number of changes and innovations in the formation of the post-totalitarian political language, as successfully analyzed by L. Yordanova in the very first years after the fall of "socialism" in Bulgaria.

In her work entitled "The Language of Change" the author, based on words (and expressions) extracted from mottos, posters and flyers (in the years of 1989, 1990, and 1991), follows up the changes in the political language as an important innovation process (according to the occasionalism - neologism scheme) in five fields [Yordanova 1993: 24-48]: 1) lexical occasionalisms - newly emerged occasional lexis that uses the play upon words and analogy (e. g. the mottos from 1989 - "A Gang of Corrupted Criminals" - BSP, and "Freely Breathing Creatures" - SDS; 2) lexical neologisms - occurred with the purpose of clarification of a new meaning or nomination of a new main point (e. g. "Never Again Stalinism and Zhivkovism! The Usurper To Trial!", "Publicity! Freedom, Democracy, Pluralism!");3) semantic neologisms - movement of layers of words with the intensified use of existing lexemas from the thematic circle of the political lexis (e. g. from the word "good luck" - "Your "good luck" took us here"; from the word "dear" - "Dear people for prison"); 4) change in the stylistic shade - changes of words by the terminological apparatus of the "socialist" society, which are of a diametrical nature (e. g. the lexema "peoples" used as "peoples criminal", the abbreviation Active Fighter Against Capitalism and Fascism (ABPFK) used as "Acknowledge us as active fighters against active fighters"; and 5) analogies in other Eastern European languages - e. g. in the German language, from which a number of lexical combinaitons of words were taken in the totalitarian period into the post-totalitarian period (e. g. "Zensur ist unkultur" - "Censorship means No Culture"; "Die Mauer im Korf muss weg" - "We need to destroy the wall in the heads", etc.).

The quite rich "stock-in-trade" of manipulation tricks - L. Yordanova concludes besides words containing positive and negative associations, also contains a number of 
other language mechanisms used (word mediators, lexemas for the original values that specify ideologemes), grammar means and specifics in the black and white drawing [Yordanova 1993: 76, 92], thus resulting in the successful development of the language manipulation strategies (including advertising and political strategies). However, in order to prepare quality language strategies, it is necessary to use one more thing - the great potential of the so-called "language" in the advertising text of the respective political subjects.

The use of the language in advertising texts was first seen in the American society in the end of the 1970s, as subsequently this phenomenon totally entered the political advertising as well. Or, from a thesis point of view, the language is usually realized via different types of speech, as it is connected with the violation of the established traditional use of the language and aims at achieving stronger power of expression and impact on the respective objects. One of its typical features is that in order to have good advertising texts, on the one hand, they must be written according to the literary norms, while realizing, on the other hand, a specific advertising modification based on the principle of expression standard [Bondzholova 2015: 63]. Depending on the above, we may also speak about the success or lack of success of a given language manipulation strategy, which is determined to a significant extent by the variants of the language .

In the specialized scientific literature the variants of the language (as manifestation of a tendency that is characteristic for the advertising texts) are connected with their creativity, attraction and originality. According to Assoc. Prof. V. Bondzholova, in view of the specifics of the phenomenon in the advertising texts and their connection with the lexical level, as well as the importance of the activities of play upon words as a component of the advertising argumentation, there are six variants of a language to be considered: quotation, with phraseology, methaphorical nomination, with syntagmatics, occasional word creation and with the black and white drawing [Bondzholova 2015: 66-67, 74-76, 78-79, $84,86-87,92]$.

1. Advertising methods (quotation).

They are directly connected with the use (directly - quotation, or transformed quotation) of precedent texts. Here the possibility for recognition is higher in case of quotation, for there are no formal changes with respect to the original text. The fact that usually this use of precedent texts in the advertising is not accompanied by specification of the source is taken into consideration, because its use results in drawing of completely different senses. Furthermore, quotation is connected with the use of precedent texts, the scope of which is very wide - literary quotations, political speaches, scientific excerpt, etc. In fact, as regards political advertising quotation is quite important, for it guarantees the preservation of the intellectual (political) tradition and succession in the activity of political parties.

\section{A play upon phraseology.}

This is such a language unit (phraseological) that is well-known, relatively stable and of a uniform meaning, the structure of which consists of a combination of words or an open sentence, having clear expressive linguistics. Usually a phraseologism consists of some type of a lexical unit, which is connected with the advertised product and which is representationed as a stimulus for the use of the respective expression. The with phraseology quite often uses winged expressions, proverbs, sayings, etc., which have a direct political impact on the electorate through advertising (e. g. the proverb "Measure seven times, cut once"). 


\section{Methaphorical nomination.}

This language play is representationed via indirect or secondary nominations, which most often represent a metaphoric transfer. These are one of the traditional forms of realization of the artistic activity of the speaker, because metaphors are used to create twodimensionality secured by the interaction of the main and auxiliary subject. They include notionally permissible combination, which creates psychological pressure in the recipient, and their unpuzzling results in an aesthetic effect - typically delight, and only upon pointing out at a problem to be solved - disapproval or digust. And furthermore - the methaphorical nomination is based on the comparison between the properties of the two objects and creates special relations of synonymy between them, and its representation as an original one-word comparison makes it useful for advertising due to the brevity and expressiveness upon calling. This nomination usually concerns the presentation of the advertised political object via one sign assessed as predominant to all other similar signs (e. g. "We Can No More").

4. Play upon syntagmatics.

The essence of this variant (syntagmatics - in Greek "syntagma" - language. 1. A doctrine for division of the speech into syntagmas, for linear disposition and connections between the language units in the text. 2. Linear relations between the language units upon their use in the speech, the text [Rechnik... 2007: 699]) is expressed in the special relations between the language signs that occur between consecutively located units upon their immediate combination (one into another) in the speech flow. Syntagmatics is interested in the study of the linear co-location of morphemes and words, as it studies the different types of combinaitons of words. Due to the fact that each lexico-semantic variant is realized in a specific context, the similar or contact use of different meanings of one and the same word, as well as of synonyms, antonyms, homonyms and paronyms, of words of the same word formation nest is usually connected with a stylistic effect and results in the higher expressiveness of the text. The play on words in political advertising is traditionally used in the with syntagmatics, the essence of which is ambiguity. It is realized within the sentence or in some piece of the advertising text, which puts focus on the key accent of the advertising political message.

5. Occasional word creation.

This type of language has an important role in word creation as a representation of the non-standard word formation (creation of occasional words). More precisely, occasionalism is each new word created for the needs of a specific text, which is the result of premeditated lexical, semantic or graphical representation of word creation. Besides, occasionalisms depend on the selected argumentation, thus necessitating the use as their motivational bases of the name of the mark (brand) or some important characteristics, which must be pointed out through the political advertising itself.

6. Play upon the black and white drawing.

This last language play covers several types of specifics completely connected with the possibility for simultaneous use of letter and non-letter signs, with the variation of two groups of signs, with their different spatial position (and layout), etc. Here we have the use of a system of graphic elements, which are a part of the visual component of the advertising text and are subject to visual perception, which, however, makes them especially important for political advertising in print media. This is so due to the fact that the with the black and white drawing in print media advertising - and differently also in 
TV advertising (such as moving letters, words and expressions), corresponds to a number of new opportunities before the verbal component, thus allowing it to vary in an unusual way and turn into an element of visual space [Rechnik... 2007: 95]. Of course, each graphic advertising image in politics is strictly specific in view of its sounding and tuning, for it depends on the specific type of political advertising.

There is no doubt that both the presented language neologisms and the varieties of a language play upon the advertising texts have a great impact on the development of the language manipulation strategies of the political advertising.

A very important moment in the unfolding of the pre-election campaigns of the parties is the rational use of political manipulation throughout the entire election process. This becomes clearly evident from the splendid analysis by L. Yordanova, who in her paper entitled "Election Strategies, Political Advertising. The Technology of Success in Parliament Elections 2005" reveals in depth the essense, content and specifics of the manipulation language strategies of all seven parliament political parties [Izborni tehnologii... 2006: 60-114] taking part in the parliament elections in 2005 and the level of development of those strategies from a linguistic point of view, let us here focus on their quantity and quality parameters (indicators, criteria) as an important component of the manipulation nature of the political market.

From the point of view of the quantity indicators as regards the manipulation (language) strategies in the pre-election campaign (2005), the following more significant results may be concluded: first, the total number of language strategies used in the campaign was 84,69 of which were repeating, i. e. ones being used more than twice by all seven parties winners of mandates; and respectively there were only 15 types of manipulation strategies applied separately by the different political parties as per their specifics; second, it is an interesting fact that the last coalition as regards the votes won - BNU, used the highest number of strategies - 16, while the first political power - Coalition For Bulgaria, used a total of 14 language strategies, and the surprise in the face of the "Ataka" Coalition used only 7 types of manipulation strategies; and third, the relatively small share of non-repeating strategies also made an impression - 15 types, as compared to the repeating strategies (69), which was not a very good testimonial for the respective political parties. Therefore, we may summarize that it is not always that the higher number of manipulation language strategies turns out to be a decisive factor for the winning of the pre-election fight, regardless of whether or not the strategies are applied at a professional level by the different political subjects or attempts are made for the "rough" introduction of specific ideas in the mass electorate consciousness.

It is far more interesting when it comes to the quality indicators upon the use of manipulation strategies: firstly from the repeating strategies - or a total of 6 times being used by five parties - the uniting (excluding the "Ataka" Coalition) and the strategy of the "key words" (excluding SDS); of 5 times - the appellate strategy, the suggestive strategy and the strategy of "contrast" (by "Coalition for Bulgaria", NDSV, MRF, BNU, and the "Ataka" Coalition). The above shows that at these parliament elections the Bulgarian parties walked a rough positive path of development as regards their democratization when on the "market of political ideas" important strategies of the type of the uniting, appellate and dialogical types are the leading ones upon the manipulative communication with the electorate. Besides the above, there are the significant strategies of the "key words", of the "magic words", and of the "language", which means quite professional attitude towards the behavior of the parties on the pre-election political market. 
Furthermore, the analysis of the quality indicators of the language manipulation strategies suggests a number of other regularities resulting from the processing of the data presented in the table. These express a negative statement, namely: the number of such manipulation strategies has been limited to two, namely manipulation strategies as the ones of the "bait" (used by DSB and BNU); of the "concretization" ("Coalition for Bulgaria" and SDS); of the "prestige" ("Coalition for Bulgaria" and MRF); of the "new words" (MRF and the "Ataka" Coalition); of the "brief language expression" ("Coalition for Bulgaria" and BNU) etc., which would be extremely efficient in the pre-election political process. It is evident that here only the "Coalition for Bulgaria" has been able to realize relatively more fully this powerful manipulative potential, which is probably one of the reasons why it has achieved the most significant election result.

Such negative tendencies may be also seen for the so-called "non-repeating strategies", where most political subjects do not count that much on the individuality of their leader, on the specifics of the party or on the innovative strategic decisions. Here the "classification" is led by NDSV having used a total of 4 strategies, followed by SDS and BNU 3 strategies, DSB -2 strategies, and the "Coalition for Bulgaria", DSB and the "Ataka" Coalition -1 strategy. However, it is more important that we have an attempt made here to find "distinctive" manipulation strategies, such as: by NDSV — of the "authority", of the "moral factor", and of the "known/unknown"; by BNU — of the "surprise", of the "image", of the "graphic means"; by SDS - of the "family" strategy, of the "feedback"; by MRF of the "hidden ethnicity" and some others. Or briefly speaking, despite used episodically (and not by all parties), non-repeating strategies obviously contribute to a certain extent to the quality unfolding of the language manipulations in the pre-election campaign.

In summary of the above as regards those manipulations, let us also add one final shade: upon the application of such an extremely rich scope of manipulation language strategies (as regards their form and contents), we may state that on the Bulgarian political market (in 2005) there were actually a whole series of new marketing techniques in politics, thus being a firm sign of its though partial, but yet more effective, quality and civilized development in the present. In view of the above, it would be hard for us to accept the explicit thesis by L. Yordanova already mentioned above, who believes that as regards manipulation - its main essence is the substitution mostly presented through the language [Izborni tehnologii... 2006: 61-62]. From the point of view of the political market as a minimum, the above is not exactly as stated by the Bulgarian linguist.

Another important moment here is connected with the various metamorphoses of the political language, which radically changes its lexical system. A number of dynamic changes have occurred, a part of which already mentioned by us, caused by specific social and psychological factors that "reform" the lexical structure of our language in two dominant tendencies, namely: according to the linguist T. Boyadzhiev the first tendency may be seen in the conscious or unconscious reaction between the "mouldy" political language of totalitarism poured on us from the forums of congresses and conferences, from the radio and TV, from the newspaper and magazine pages, etc.; and the second tendency expressed in the great strive for an expression and variety, which to a great extent determines the efforts of the media and journalists to come closer to the political language, to the simple efficiency of the street eloquence and verbosity. Meanwhile, the above has resulted in a drastic change in the political phraseology, which has been filled in via methaphorical derivation with binomial combinations of words, such as "gentle revolution", "national consent", 
"round table", the "city of truth", "consumer basket", "social partnership", "parliament space", "constitutional order", etc., as well as with new units [Boyadzhiev 1994: 48-49], which reflect the common changes in reality, such as the abstract lexis formed by the suffixes -ism (totalitarism, chieftainism), -ure (nomenclature, juncture), -ion and -om (destruction, millionairedom), -ism and -ity (oppositionism, convertibility), etc.

After the 2001 elections, for example, the so-called "tsar's subject" became the subject of a widely spread language top crust, which literally clogged the Bulgarian political language for a certain period of time. And just a small part of this vivid language and political palette called by Prof. P.-Em. Mitev "tsar's" language nest" [Mitev 2005: 20]: "tsar's euphoria", "tsar's charisma”, "tsar's”, "tsar's movement", "tsar's sheets", "tsar's patience”, "tsar's head of personnel department ", "tsar's people”, "tsar's lackeys", "tsar's tram drivers", "tsar's strategists", "tsar's cart”, "tsar's pickles”, “tsar's Republic", etc.

As regards the language after the parliament (2005) and president (2006) elections developed in a similar way, when the new party called "Citizens for European Development of Bulgaria” stepped on the political stage, the informal leader of which was the former mayor of Sofia. In this case we may conclude that the so-called "GERB language nest" was created being known for its also quite colorful language pack, such as "Gerbisti”, "Gerberi”, "Gerbove”, "Grabisti”, "Gerbadzhii”, "Gerbovi marki”, "Gerbovi znatsi”, etc., and other linguistic people's identifications, which obviously come with each new political formation, regardless of which and what it is.

Generally speaking, during the Bulgarian transition - Prof. Venche Popova points out - " a new wave flooded the language of the political discourse - from its typical conventional, logical, terminological speech to the rascal speech and the illiterate sentence. A base of the political oration, disregard of the standardized language and search for more and more vivid mechanisms for efficient political speech" [Popova 1995: 201]. However, it's a pity that: these mechanisms for efficient political speech cannot be seen yet despite the fact that different politicians tend to claim otherwise [Manolov 2008: 113-125].

In fact, the political language is one of the most skillful "manipulators" of the electorate, without which the existence of the political advertising as a quality product on the political market would be absolutely impossible. However, the above poses the important question about the role of manipulation in political advertising and on its ability to turn upside down the emotional (and political) ideas stuck deep inside the public consciousness. (Manipulation - from French, manipulation - from Latin - a combination of someone's actions and movements that have a specific target purpose; an adroit act, a dodge, a fraud; skillful execution of something, of some activity with preset and usually hidden purposes [Rechnik... 1970: 425]. Political manipulation - a purposeful message to people, which aims through specifically selected forms, means and mechanisms to follow the concealment of the actual intentions of a given political subject (a person or a party) as regards other subjects and objects, through the broadcasting of various pseudo-information with the purpose of the complete delusion of the public opinion [Manolov 2005: 128-135].) Or directly speaking, isn't the political advertising a main method for manipulation, when it can have a radical impact on large masses of people? Besides, the manipulation of the political advertising is like the double-faced Janus, i. e. it has two distinctive features: the first one is the positive (in positive political adds), which is bidirectional, constructive and positive; while the second one is the negative (in negative political adds), which is displayed as unidirectional, blackening, destructive, 
discrediting, etc. In other words, the positive political advertising is approbated with the help of the techniques of the convincing communication, while the negative one uses the mechanisms of the "black", "grey", "yellow" and any other similar political PR. In view of the above, we may state that the professionally made political advertising "spreads out" between the reality and manipulation, between the truth and lie, and between the image and the pseudo-image (of politics). In view of the above, let us formulate ten manipulation rules of the political advertising, which in our opinion are at the very base of the good advertising and of the quality pre-election campaign.

The rules have been developed by the author by also using the thoughts on manipulation of two contemporary authors - Ryan Holiday and J. Kirchner [Holiday 2017: 63-153; Kirchner 1995: 212, 227-230].

1. Brand establishment.

This rule is of crucial importance for the quality political advertising, for its absence would be as if we had no subject of politics to establish in the electorate consciousness. In other words, the political mark here is the identification, the emblem and the sign of the respective political subject (either group, or personal), through whom the electorate manages to recognize (get to know, acknowledge) the separate players in the pre-election campaign.

2. Successful device (slogan, motto).

In this case it is a must to find the most precise, clearest and most adequate expression of the authenticity of the political subject (the party, the Coalition, the leader), with which the same is distinguished from all other opponents. It is also important to find the crosspoint between the offered party identity (right, center, left) and the different electorate segments (not only one's own electorate) in order to achieve the maximum impact of the applied manipulation effect.

By the way, let us mention here that in his book entitled "The Art and Science of the Advertising Slogan" the explorer Timothy Foster presents the following more significant rules to develop a quality advertising motto: 1 ) it should be easy to remember; 2) it should repeat the brand's name; 3 ) it should contain a key benefit; 4) it should distinguish the brand; 5) it should add positive feelings to the brand; 6) it should reflect the individuality of the brand; 7) it should be strategic; 8) it should be fit for campaign purposes; 9) it should be competitive; 10) it should be original; 11) it should be simple; 12) it should be clear; 13) it should be plausible; 14) it should urge on liking; 15) it should direct towards use; 16) it should be no longer used by anyone else; 17) it should not be boring; 18) it should not provoke sarcasm (or negativism); 19) it should not be exacting; 20) it should not be negative; 21) it should not use broad statements; 22) it should not be a standard statement (e. g. "And so what?"); 23) it should not make us exclaim with cliché expressions (e. g. "Is that so?"); 24) it should not be pointless; 25) it should not be complex and tactless; and 26) it should be made so that people like it [Stoyanov 2017: 83].

3. Let them hear what they want.

This archaic marketing technique resembles a political axiom for future electorate success, because it is well-known that all "pleasing" rumours almost always turn into reality, when the electorate stands in front of the ballot-boxes. and furthermore, it is appropriate to remind that human consciousness is made so that it usually perceives what it hears as the reality, and the future one as a real one, and that is in a way that it "gets permanently stuck" in its thoughts. 


\section{Easy Messages.}

Such a rule is prompted by the nature of the pre-election fight, where the messages of the parties (and the candidates) should be convenient and easy to perceive, for they aim at convincing a maximum number of electorate. That's why messages should not be "heavy", clumsy and long combinaitons of words, but instead should have a precise, short and wellconsidered expression. Furthermore, these should be also ones of deep meaning, i. e. they should reflect the essence of the subject advertised by them.

5. Language manipulation.

The art of this manipulation literally means one significant thing - to say what the public is to remember, to keep repeating what the public wants to hear, and to listen to the public opinion (regardless of its nature). In view of the above, the language of politicans can actually and should turn into one of the most important tools of the pre-election political advertising. This usually happens through the use of the so-called "manipulative charge" ("the quantity of explosive") of the specific text immanent in every political advertising. Due to the fact the manipulation always stakes on one and the same postulates life - death, good - evil, human - beast [Panayotov 2002] and so on, out of which there is only one exit given: the exit that is convenient for the advertising political subject.

6. "Selling" the charisma.

In this case, the make of good advertising would be eased if it is directed towards a charismatic political image. However, the above doesn't mean at all that the charisma itself works towards more electorate votes. On the contrary, the skill here is how to rationally "weave" the natural fact of the charismatic leader for example into high-quality political advertising, where the charisma is not some type of an intruding "stranger", but a natural element of its make.

\section{Brief speaking.}

In the political advertising the precise expression, the brief expression and the brief speaking are like the "Laws of God" in pre-election campaigns. Due to the above, it is true mastership to make the advertising "speak" clearly and briefly, and that should be in a way that most people perceive the message to them (irrespectively of their intellectual, educational and other capacity).

\section{Conscious repetition.}

According to J. Kirchner the results from the realization of the repetition (law) may be achieved through the use of four language methods: a) "better say ten times "yes" that one time "no"; b) "provoke your opponent with a tiny trick", or with such behavior, where we act as if we know all about it; c) "provoke the fantasy of your opponent in order to present what you want to convince him in"; d) "confuse your opponent by turning small details into a major problem" [Kirchner 1995: 212, 227-230].

9. Imagine but do not lie.

In most cases the question here comes down to the thing most hard to get: to use artistically thinking in advertising (and its make), without violating the rules of the political fair play. This is a really tough task, which however can be resolved as long as there are no vulgar extremes or ideological reels.

10. "Manipulate properly".

This last rule contains the quintessence of manipulation through political advertising. A fair norm is always to be observed here, as its purpose is to protect us against absolutizations while preparing the political advertising. In other words, it would be the right thing 
to depend on some integrated criteria for manipulation defined by the Russian scientist E. Dotsenko as: a psychological impact, an attitude towards the object of manipulation, a strive for obtaining unilateral benefit, hidden nature of the impact, motivational stimuli and matersly realization of the manipulation [Dotsenko 1996: 58]. Thus, it is practically possible to distinguish the somewhat inevitable nature of the political manipulation in the advertising from the hypermanipulation in the political advertising aiming at the distortion of reality via pseudo-truthful messages to the public.

Is there a distinctive line between the actual (i. e. impactful) and manipulated (i. e. distoring) political advertising?

The answer to this question is ambiguous: the first meaning completely concern the non-distorted application of the specified ten rules for manipulative make of the political advertising; while the second one is a true "double" (copy) of the total manipulation through advertising in politics, which especially during elections is what the public wants to be true, the Utopia - to be reality, the future - to be present, and so on. (In this context, some authors are right upon distinguishing two types of manipulation: the first one is used upon presentation of ideas, in which the object to manipulation believes; and the second one aims at concealing the true beliefs of the author by enforcing ideas other than his. In other words, the term "manipulation" here acquires a negative load as a text and as a perception by the public [Minkov 2002: 142].) This is also expressed in that fine line between reality and manipulation in political advertising, which very often grows from rules into anti-rules, from truth into lie, from justice into injustice, etc.

Conclusions. As a conclusion to the connection between language manipulation strategies and pre-election political advertising in our country, we can say the following: regardless of the huge variety of the specified language strategies and their different displays, the political advertising used does not differ significantly from them both with respect to its make and with respect to the targets of its purpose. In other words, in brief, the pre-election political advertising, besides being made professionally, almost always is in full compliance with the political party values and strives for meeting the electorate expectations, thus also realizing the "canons" of the language manipulation strategies. In other words, it also comes up to a great extent to the psychological impact on the electorate, which is an essential element of the characteristics of the modern political advertising.

In almost all cases during the election campaigns, the used political advertisement has an overt or covert (subtext) manipulative character, which with the help of the language play, succeeds to involve many voters in the name of one or another political (and party) cause.

\section{References}

Bondzholova, V. (2015). Osobenosti na reklamnia ezik i stil. Leksikalen aspekt [Specifics of Advertising Language and Style. Lexical Aspect]. Veliko Tarnovo. (In Bulgarian)

Boyadzhiev, T. (1994). Knizhovniat ezik v savremennoto obshtuvane [Literary Language of Contemporary Communication]. Ezik i literatura [Language and Literature], 4, 48-49. (In Bulgarian)

Dotsenko, E. L. (1996). Psihologia manipulyacii [Psychology of Manipulations]. Moscow. (In Russian)

Holiday, R. (2017). Istinata e: az lazha. Izpovedta na edin medien manipulator [Trust Me, I'm Lying: Confessions of a Media Manipulator]. Sofia. (In Bulgarian)

Izborni tehnologii. Parlamentarni izbori 2005 [Election Technologies. Parliament Elections 2005]. (2006). Sofia. (In Bulgarian) 
Kirchner, J. (1995). Manipulirayte, no pravilno [Manipulation: Eight ways to control others]. Sofia. (In Bulgarian)

Manolov, G. (2005). Politicheskiat imidzh - formulata na uspeha [The Political Image - the Formula for Success]. Plovdiv. (In Bulgarian)

Manolov, G. (2008). Politicheskiat pazar. Tom II. Bulgarskiat politicheski pazar [The Political Market. Vol.II. The Bulgarian Political Market]. Plovdiv. (In Bulgarian)

Minkov, St. (2002). Manipulacionni tehniki v programnite dokumenti na Hitler i Musolini [Manipulation Techniques in the Program Documents of Hitler and Mussolini]. In D. Dobrev (Ed.), Tekstat kato manipulacia [Text as Manipulation]. Shumen, 142 (In Bulgarian)

Mitev, P.-Em. (2005). Politicheskoto govorene predi i sled izbori [Pre- and Post-election Political Speaking]. Standart [Standard], 19.XII.2005, 20. (In Bulgarian)

Panayotov, V. (2002). Tezisi kam tekstovata manipulativnost [Theses to Text Manipulation]. In D. Dobrev (Ed.), Tekstat kato manipulacia [The text as manipulation]. Shumen, 12-13 (In Bulgarian)

Popova, V. (1995). Vulgarizaciata v ezika na politicheskata statia [Vulgarization in the language of the political article]. Problemi na sociolingvistikata [Problems of Sociolinguistics]. Sofia, 201 (In Bulgarian)

Rechnik na chuzhdite dumi v bulgarskia ezik [Vocabulary of foreign words in the Bulgarian language]. (1970). Sofia. (In Bulgarian)

Rechnik na chuzhdite dumi v bulgarskia ezik [Vocabulary of foreign words in the Bulgarian language]. (2007). Sofia. (In Bulgarian)

Stoyanov R. (2017). Politicheski komunikacionni praktiki [Political Communication Practices]. Sofia. (In Bulgarian)

Yordanova, L. (1993). Ezikat na promyanata [The Language of Change]. Sofia. (In Bulgarian)

Received: September 15, 2018

Accepted: October 22, 2018

Author's information:

Georgi L.Manolov — PhD, Professor; manolovi@gmail.com

\section{Манипулятивные языковые стратегии в болгарской политической рекламе}

\section{Г. Л. Манолов}

Высшая школа безопасности и экономики,

Болгария, 4000, Пловдив, Кукленско шоссе, 13

Для цитирования: Manolov, G. L. (2018). Language manipulation strategies of the political advertising in Bulgaria. Медиалингвистика, 5 (4), 545-556. https://doi.org/10.21638/spbu22.2018.412 (In English)

В данной статье анализируются особенности функционирования термина «манипулятивные языковые стратегии» в Болгарии. Разъясняются понятия манипуляции и демонстрации ее значимости в разных предвыборных кампаниях. Дается описание средств манипулятивных языковых стратегий, рассматривается их научное понимание, а также основные функции в предвыборных кампаниях. В статье представлены ключевые особенности так называемых языковых перемен, отразившихся в речи после 10 ноября 1989 года, такие как лексические окказионализмы, семантические неологизмы, изменение тональности и т.д. Автором детально проанализирована так называемая языковая игра в рекламных текстах соответствующих политических тем. Рассмотрены шесть наиболее востребованных видов языковой игры: игра на основе цитации, обыгрывание фразеологизмов, метафорические номинации, обыгрывание синтагматических связей, создание окказионализмов, графические игры. Все разновидности языковых игр проиллюстрированы соответствующими примерами из предвыборных кампаний. Особое внимание уделено особенностям манипуляции в политической ре- 
кламе, таким как создание бренда, эффектный слоган, простота тезисов, «продажа» харизмы, краткость формулировок, сознательный повтор, подлог, отсутствие лжи, «честные» манипуляции.

Ключевые слова: манипулятивные языковые стратегии, языковая игра, манипуляция, политическая манипуляция, правила политической манипуляции

Статья поступила в редакцию 15 сентября 2018 г.; рекомендована в печать 22 октября 2018 г.

Контактная информация:

Манолов Георгий Любенов — PhD, Professor; manolovi@gmail.com 